\title{
High-pressure-washing to manage insect infestations on capsicums
}

\author{
N.E.M. Page-Weir ${ }^{1}$, L.E. Jamieson ${ }^{1}$, S.P. Redpath ${ }^{1}$, M.J. Griffin ${ }^{1}$, S.R. Olsson ${ }^{1}$, \\ A. Chhagan ${ }^{1}$, P. Biswas ${ }^{2}$ and A.B. Woolf ${ }^{1}$ \\ ${ }^{1}$ The New Zealand Institute for Plant \& Food Research Limited, Private Bag 92169, \\ Auckland 1142, New Zealand \\ ${ }^{2}$ Southern Paprika Limited, 504 Woodcocks Road, Warkworth, Auckland, New Zealand \\ Corresponding author: Natalie.Page@plantandfood.co.nz
}

\begin{abstract}
Pests on capsicum fruit can cause market access issues resulting in costly methyl bromide fumigation. High pressure washing (HPW) removes insects and other surface contaminants and has been commercialised for capsicums. This paper reports on performance of a commercial HPW system and compares it to an experimental HPW system that the commercial system was based on. The experimental high-pressure washing system operated at 75 or $100 \mathrm{psi}$ ( 517 or $689 \mathrm{kPa}$, respectively) resulted in complete removal of aphids on capsicum fruit. The commercial washer at the same pressures removed $98.1-98.9 \%$ of aphids resulting in 85-95\% clean fruit. HPW treatment increased incidence of soft rot and stem blackening with higher rot blackening at 100 psi. These results indicate the potential of HPW to be included as a mitigation measure in a systems approach to improve market access for capsicum. However, further optimisation in a commercial setting and evidence for efficacy against other pests of capsicum, such as tomato potato psyllid is required.
\end{abstract}

Keywords disinfestation, insect removal, washing, waterblasting, aphids, pests, systems approach.

\section{INTRODUCTION}

New Zealand exports fresh capsicums (Capsicum annuum L.), with the two markets of Japan and Australia comprising $98 \%$ of all capsicum exports. In 2013, 15,000 tonnes of capsicums were exported, with a value of NZ\$38 million (HortNZ 2014). The presence of pests, i.e. aphids, mealybugs, thrips, mites and psyllids, can cause market access issues. The tomato potato psyllid, Bactericera cockerelli (Sulc) Hemiptera: Triozidae, is a particularly serious production (Liu \& Trumble 2004) and quarantine pest, and since its arrival in New Zealand has resulted in more stringent phytosanitary requirements for some markets (Teulon et al. 2009).
The presence of species of quarantine importance results in costly methyl bromide fumigation, which also significantly reduces out-turn quality of capsicums (E.M. O’Donoghue, Plant \& Food Research, personal communication). In some countries, fumigation prior to export is mandatory for access; in others fumigation may be required at the border.

Non-chemical postharvest disinfestation treatments are being sought and high-pressure water-washing (HPW) is one possible risk reduction option. Previous HPW trials with capsicums found a significant decrease in mealybug infestation after treatment (Jamieson 
et al. 2010) and a decrease in postharvest disease, even under high pressure from fungal rots (O’Donoghue et al. 2013).

An advantage of treatments that remove pests compared with those that simply kill, is the absence of any observable sign of pest infestation on arrival in overseas markets. This increases the likelihood the product line will move through the importing border. HPW has been effective at decreasing the number of surface pests on fruit, such as apples (Whiting et al. 1998a), avocados (Jamieson et al. 2000), kiwifruit (Whiting et al. 1998b), pears (Hansen et al. 2006) and capsicums (Jamieson et al. 2010).

HPW is used commercially, as an industry standard, in New Zealand apple and avocado packhouses before fruit is sent for export (Woolf et al.2015) and is starting to be used commercially as a treatment for capsicums within a systems approach to control insects and disease. As defined in ISPM 14, a systems approach is the integration of different pest management measures, at least two of which act independently, and which cumulatively achieve the appropriate level of phytosanitary protection (IPPC 2014). Control measures can be applied before harvest (insect control by insecticides) or after harvest (grading and cleaning, fumigation, cold storage).

It has been difficult to conduct disinfestation research to assess efficacy of tomato potato psyllid on capsicums, due to the low propensity for female adults to oviposit on capsicum fruit including calyx and stems (N.E.M. Page-Weir, unpublished data). Therefore, to assess the pest removal efficacy of HPW, other pests, such as aphids, are used to measure efficacy. This research aimed to assess the performance of a commercial HPW system in terms of aphid removal and impact on capsicum quality, by comparing its performance with an experimental HPW system.

\section{MATERIALS AND METHODS}

\section{High-pressure washing (HPW) systems}

Experimental and commercial HPW systems were compared for aphid removal efficacy. Aphids were used as a proxy for general pest removal from capsicum fruit. An associated fruit quality trial was carried out only on the Plant \& Food Research (PFR) experimental HPW.

The experimental HPW system was based on the "standard" HPW system used in New Zealand for apples (also referred to as Honiball; Woolf et al. 2015) with the modification of angled nozzles as described by O'Donoghue et al. (2013) and Woolf et al. (2014). Briefly, the system consists of eight rows of nozzles (ProMax ${ }^{\circledR}$ QuickJet $^{\circledR}$ Spray Tips - QPTA-15-40: Spraying Systems, Auckland, New Zealand) over a rotating brush bed where fruit are treated for ca $15 \mathrm{~s}$. The brush-bed is fixed, meaning that fruit-to-fruit contact moves fruit through the washer (Woolf et al. 2014).

The commercial HPW system was located on the packing line at Southern Paprika Ltd (SPL), Warkworth, New Zealand. This HPW unit was substantially similar to the experimental HPW machine (nozzle type, orientation, flow rate, distance to fruit and distance between nozzles), but with some differences, including only four rows of nozzles that are not angled and a moving brush bed. Fruits are carried under the nozzles for an average treatment time of ca $7 \mathrm{~s}$.

\section{Aphid removal}

Red capsicum fruits ('Stayer', Grade 2) were sourced from a commercial supplier on 10 June 2014. On the morning of 11 June, green peach aphids (Myzus persicae) were collected from a colony reared on bok choy (Brassica rapa subsp. chinensis). Aphids were transferred onto the stem/ calyx area of each fruit by gently brushing from an infested leaf onto the fruit with a soft bristle paintbrush. This resulted in a mixture of nymphal stages and adults being transferred onto each fruit. Each fruit had between 50 and 100 aphids prior to the application of HPW treatment.

Approximately 3-5 hours after infestation with aphids, 60 infested capsicum fruits were processed through the experimental HPW system at 50, 75 or 100 psi. A second set of 120 fruits was transported to the commercial HPW unit at SPL, where 60 fruits were processed through the commercial HPW system at water pressures of 50, 75 or 100 psi. The remaining 60 fruits were used as untreated controls. Following treatment 
completion, fruit was packed into clean boxes and transferred to Plant \& Food Research, Mt Albert, where numbers of aphids remaining on each fruit were assessed within $24 \mathrm{~h}$ of treatment. A stereo microscope was used to thoroughly examine each fruit for aphid presence at the top and underside of the calyx. Aphid numbers, location on the fruit and live/dead status were recorded for each fruit.

\section{Fruit quality}

Capsicum fruits ('Stayer', Grade 2) was obtained from a commercial supplier and treated with the experimental HPW system. Fruits were randomly assigned to treatments (no-wash control, 75 and 100 psi). Three replicate runs of ca 10-12 fruit were carried out for each treatment. Control fruits were moved through the wet brush roller bed without high-pressure washing, thus simulating a wet-brushing system. Treated and control capsicums were left to air-dry at ambient temperature (ca $1 \mathrm{~h}$ ), then packed into standard capsicum cartons.

All fruits were held at $10^{\circ} \mathrm{C}$ with $90-95 \%$ relative humidity for 9 days, simulating a relatively short storage period. The fruit quality was visually assessed for the incidence of soft rots (water-soaked, dark sunken lesions and secondary pathogen invasion on fruit surface), stem blackening (stem die-back) and stem rots (caused by Rhizopus and Botrytis). Rots and stem blackening incidence was expressed as percentage of the total number of fruit.

\section{Statistical analysis}

Aphid numbers on fruit prior to washing was estimated using mean infestation obtained from unwashed controls. These data were used to estimate the total percent remaining after washing. Percentages of aphids remaining, fruit with soft rots, stem blackening and stem rots were angular transformed and then compared amongst treatments using Analysis of Variance (ANOVA). Least significant differences (LSDs) were calculated to show treatments where the ANOVA demonstrated significant differences $(\mathrm{P}<0.05)$. The analyses of aphid removal were performed using GenStat (14 ${ }^{\text {th }}$ edition). The analysis of fruit quality data was performed using Microsoft Office Excel 2007.

\section{RESULTS}

\section{Aphid removal}

Fruits were not completely dry when assessed and some aphids appeared dead (no movement when prodded), but they may have been waterlogged and still alive. Therefore, the numbers of live and dead aphids remaining on the fruit were combined to calculate the percentage removed.

There were significantly fewer aphids after experimental or commercial HPW $(\mathrm{P}<0.05)$ than found on unwashed fruit. HPW at 50 psi using the experimental or commercial system removed $96.7 \%$ or $97.8 \%$ of aphids (compared to untreated fruit), resulting in 85 or $95 \%$ clean fruit, respectively (Table 1). All aphids were removed after capsicums were washed using the experimental washer at 75 or 100 psi. In comparison, the commercial HPW system was less effective at removing aphids at the higher pressures and removed 98.1-98.9\% of aphids (compared to untreated fruit) resulting in $85-95 \%$ clean fruit. Of the aphids found after HPW treatment, the majority were located under the calyx, particularly at the lower pressures on the commercial washer (Table 1).

\section{Fruit quality}

Fruit exposed to water pressures of 100 psi showed a higher percentage of soft rot (watersoaked, dark sunken lesions and secondary pathogen invasion) than fruit treated with 75 psi (Table 2). No control (wet brushed) fruit developed soft rots.

Stem blackening was present in control fruit $(8.5 \%)$, but incidence was significantly increased by HPW at 100 psi. There was no significant increase in stem rots with HPW.

\section{DISCUSSION}

The experimental HPW system operating at 75 and 100 psi removed all aphids, whereas the commercial HPW system removed $75-95 \%$ of aphids at these pressures, suggesting that 
Table 1 The number and percentage of green peach aphid remaining and the proportion of fruit infested and location of aphids (expressed as \% of total aphids found for each treatment) after using an experimental high-pressure washer or a commercial high-pressure washer. Bars with the same letter were not significantly different $(\mathrm{P}>0.05)$.

\begin{tabular}{|c|c|c|c|c|c|c|}
\hline \multirow[b]{2}{*}{ Treatments } & \multicolumn{2}{|c|}{ Aphids remaining } & \multirow[b]{2}{*}{$\begin{array}{c}\text { Fruit infested } \\
\text { after HPW (\%) }\end{array}$} & \multicolumn{3}{|c|}{$\begin{array}{c}\text { Proportion of aphids at each } \\
\text { location }(\%)\end{array}$} \\
\hline & No./fruit & Mean \% & & Fruit & On stem/calyx & $\begin{array}{l}\text { Under } \\
\text { calyx }\end{array}$ \\
\hline Untreated $(n=59)$ & 13.5 & 100 & 100 & 25.3 & 52.2 & 22.5 \\
\hline \multicolumn{7}{|c|}{ Experimental ( $\mathrm{n}=20$ for each pressure treatment) } \\
\hline 50 psi & 0.5 & 3.3 & 15 & 0 & 22.2 & 77.8 \\
\hline 75 psi & 0 & 0 & 0 & 0 & 0 & 0 \\
\hline $100 \mathrm{psi}$ & 0 & 0 & 0 & 0 & 0 & 0 \\
\hline \multicolumn{7}{|c|}{ Commercial ( $\mathrm{n}=20$ for each pressure treatment) } \\
\hline 50 psi & $0.3^{1}$ & 2.2 & 5 & 0 & 0 & 100 \\
\hline 75 psi & 0.3 & 1.9 & 5 & 0 & 0 & 100 \\
\hline $100 \mathrm{psi}$ & 0.2 & 1.1 & 15 & 33.3 & 66.7 & 0 \\
\hline
\end{tabular}

Table 2 Incidence (\%) of soft rot, stem blackening and stem rot of fruit treated with experimental HPW, using pressures of 75 or 100 psi then stored at $10^{\circ} \mathrm{C}$ for 9 days. Control fruit were wet-brushed only.

\begin{tabular}{lccc}
\hline Treatment & Soft rot & Stem blackening & Stem rot \\
\hline Control & $0.0 \mathrm{a}$ & $8.5 \mathrm{a}$ & $11.4 \mathrm{a}$ \\
$75 \mathrm{psi}$ & $11.4 \mathrm{~b}$ & $14.2 \mathrm{a}$ & $11.4 \mathrm{a}$ \\
$100 \mathrm{psi}$ & $17.1 \mathrm{~b}$ & $20.0 \mathrm{~b}$ & $17.1 \mathrm{a}$ \\
\hline
\end{tabular}

Percentages with a common letter within a column were not significantly different $(\mathrm{P}>0.05)$.

the commercial HPW systems needs further modifications to enhance removal. Although not statistically significant, the experimental system may have removed more aphids because this unit treated fruit for longer (ca $15 \mathrm{cf} .7 \mathrm{~s}$ ) with a greater number of water jets (i.e. $8 \mathrm{cf}$. 4 rows of nozzles).

From a fruit quality perspective, the experimental HPW treatment increased both soft rot and stem blacking incidence compared with the control (wet-brushed) fruit, with incidence generally increasing with increased water pressure. These results suggest that washing pressures below 75 psi might be more appropriate for capsicums. However, this is in contrast with earlier findings that indicated better quality capsicums after HPW treatment (O'Donoghue et al. 2003). A high pressure waterwashing treatment using 75 psi followed by a 30 -s hot water drench at $55^{\circ} \mathrm{C}$ (a heavy shower of hot water) and hot air drying resulted in better quality capsicums than the standard commercial treatment dipping in a fungicide (Olsson et al. 2009). It should be noted that the fruit used in this current study was of reduced at-harvest quality due to being very late-season fruit, and this may have contributed to the propensity to damage, particularly rots. Similar trials using main harvest, higher quality fruit are required to validate the present results. Also, incorporating a hot water drench after HPW and faster drying conditions as reported by Olsson et al (2009) may assist with reducing the risk of rots.

Based on the findings of the present experiments, the pressure range of future HPW work should span 50, 75 and 100 psi and incorporate a hot water drench and fast drying conditions. Jamieson et al. (2010) reported that HPW using pressures between 50 to 100 psi removed $60-80 \%$ of mealybugs from heavily infested capsicums that had a mean of 12-37 live mealybugs on before HPW. 
Future trials should assess the removal of tomato potato psyllid eggs and nymphs from capsicum fruit. This will be difficult to demonstrate because of the low propensity for tomato potato psyllid to lay eggs on capsicum fruit (N.E.M. PageWeir, unpublished data). However, the poor host status of capsicum fruit for tomato potato psyllid should be taken into account in risk analyses for this major pest on capsicums.

\section{ACKNOWLEDGEMENTS}

This project was funded by the Ministry of Business, Innovation and Employment via Plant \& Food Research Core funding. Thank you to Robin Gardner-Gee and Aleise Puketapu for providing adult tomato potato pysllids; Vicky Davis and Manoharie Sandanayaka for providing green peach aphids; Southern Paprika Ltd and New Zealand Hothouse for providing fruit for trials; Dave Rogers and Erin O'Donoghue for their comments on the paper.

\section{REFERENCES}

Hansen JD, Heidl ML, Neven LG, Mielke EA, Bia J, Chen PM, Spotts RA 2006. Effect of highpressure hot-water washing treatment on fruit quality, insects, and disease in apples and pears: Part III. Use of silicone-based materials and mechanical methods to eliminate pests. Postharvest Biology and Technology 40: (3) 221-229.

HortNZ 2014. Covered crops. http://www. freshvegetables.co.nz/crops/covered-crops/ (accessed 28 October 2014).

IPPC 2014. ISPM No. 14. 2002. The use of integrated measures in a systems approach for pest risk management. IPPC, FAO, Rome, Italy. $40 \mathrm{pp}$.

Jamieson LE, Whiting DC, Woolf AB, White A, McDonald RM 2000. Water-blasting avocados to remove leafroller eggs. New Zealand Plant Protection 53: 371-374.

Jamieson LE, Page-Weir NEM, Chhagan A, Olsson S, Connolly PG, McDonald RM, Woolf A 2010. High pressure water-washing to remove pests from capsicums. New Zealand Plant Protection 63: 118-122.
Lui D, Trumble JT 2004. Tomato psyllid behavioural responses to tomato plant lines and interactions of plant lines with insecticides. Journal of Economic Entomology 97: 1078-1085.

O'Donoghue EM, Somerfield S, McLachlan A, Olsson S, Woolf A 2013. High-pressure water washing and continuous high humidity during storage and shelf conditions prolongs quality of red capsicums (Capsicum annuum L.). Postharvest Biology and Technology 81: 73-80.

Olsson S, O’Donogue E, Brummell D, Jamieson L, McDonald R, Woolf A 2009. Effect of high pressure water-washing and hot water drench on postharvest quality of capsicums. Postharvest Pacifica 2009, Australasian Postharvest and Managing Quality in Chains Conference, 15-19 November 2009, Napier, New Zealand. p. 123.

Teulon DAJ, Workman PJ, Thomas KL, Nielsen MC 2009. Bactericera cockerelli: incursion, dispersal and current distribution on vegetable crops in New Zealand. New Zealand Plant Protection 62: 136-144.

Whiting DC, Hoy LE, Maindonald JH, Connolly PG, McDonald RM 1998a. High-pressure washing treatments to remove Obscure mealybug (Homoptera: Pseudococcidae) and Lightbrown apple moth (Lepidoptera: Tortricidae) from harvested apples. Journal of Economic Entomology 91 (6): 1458-1463.

Whiting DC, Hoy LE, Connolly PG, McDonald RM 1998b Effects of high-pressure water jets on armoured scale insects and other contaminants of harvest kiwifruit. New Zealand Plant Protection 51: 211-215.

Woolf A, McDonald R, Rogers D, Olsson S, Redpath S, ODonoghue E, Kagy V, Mille C, Cate L, Griffin M, Page-Weir N, Chhagan A, White A, Walker J, Jamieson L 2015. Advances in application of high pressure washing to enhance market access. International Horticulture Congress (August 2014), Brisbane, Australia. Acta Horticulturae (in press). 